удк 616.211/.711:371.7-053

Володимир Бесєда

Національний педагогічний університет імені М. П. Драгоманова

ORCID ID 0000-0003-4262-6629

DOI 10.24139/2312-5993/2019.08/365-377

\title{
ВИДИ І ПРИЧИНИ ПОРУШЕНЬ ПОСТАВИ В САГІТАЛЬНІЙ ПЛОЩИНІ У ДІТЕЙ РАННЬОГО І ДОШКІЛЬНОГО ВІКУ ІЗ ЗАТРИМКОЮ ПСИХОМОТОРНОГО РОзвиткУ
}

\begin{abstract}
Метою даної статmі $\epsilon$ створення класифікації порушень постави в сагітальній площині дітей раннього та дошкільного віку з затримкою психомоторного розвитку. Аналіз літературних джерел дозволив виділити основні етіологічні ознаки порушень постави в даної категорії дітей, що дозволило визначити їх у блоки та срормувати класифікацію порушень постави, яка полегшує педагогам орієнтування у відхиленнях постави в дітей.

Перспективи подальших досліджень можуть полягати в більш докладній деталізації причинно-наслідкових відносин етіології і патогенезу порушень постави в сагітальній площині.
\end{abstract}

Ключові слова: dimи, постава, порушення постави, хребет, кіроз, лордоз, діагностика.

Постановка проблеми. Захворювання опорно-рухового апарату традиційно посідають одне з перших місць у структурі патології дітей раннього та дошкільного віку. За даними різних авторів, різні форми порушень постави зустрічаються частіше, ніж інші відхилення. Так, згідно $з$ даними досліджень, порушення постави різних видів відзначається сьогодні в 63 \% обстежених школярів, а починаються вони ще 3 дошкільного віку (Валецька, 2007). У дітей дошкільного віку поширеність порушень постави складає 70-80 \% (Глоба, 2011).

Аналіз актуальних досліджень. Актуальність вирішення проблеми профілактики й корекції порушень постави дітей обумовлена не тільки фактом наявності порушення постави дитини, скільки несприятливим прогнозом, пов'язаним із наслідками для всього організму в цілому. У науковій літературі представлені дані про роль порушень постави у формуванні та розвиткові структурних деформацій хребетного стовпа, що згодом сприяє появі таких негативних факторів, як: розвиток стійкого больового синдрому; формування патологічного рухового стереотипу; розвиток функціональних суглобових блокад; виникнення міофасціального больового синдрому; зміна біомеханіки хребта й тіла в загальному; розвиток дегенеративно-дистрофічних змін у міжхребцевих дисках і зв'язковосуглобового апарату; розвиток остеохондрозу; розвиток гриж міжхребцевих дисків; зміни топографії органів грудної клітини; погіршення діяльності 
органів черевної порожнини; недостатня рухливість діафрагми і зменшення коливань внутришньогрудинного і внутрішньочеревного тиску; негативний вплив на серцево-судинну систему; дисфункції травлення; погіршення діяльності центральної нервової системи та ін. (Васильева, 1999; Васильева та Кузнецов, 2011; Кашуба, 2003; Никлоаев, 1947; Потапчук та Дидур, 2001; Snell, 1992).

Мета дослідження - створення класифікації порушень постави в сагітальній площині дітей раннього та дошкільного віку в залежності від причин їх виникнення, адаптовану до можливостей корекційно спрямованого фізичного виховання.

\section{Завдання дослідження:}

1. Проаналізувати існуючі сучасні класифікації порушень постави в дітей.

2. Виявити основні причини порушень постави в сагітальній площині в дітей раннього та дошкільного віку та сформувати їх в умовні блоки.

3. Запропонувати адаптовану для можливостей корекційного фізичного виховання класифікацію порушень постави в дітей у сагітальній площині.

\section{Методи дослідження:}

- історичний метод - надає змогу дослідити виникнення, формування та розвиток наукових досліджень щодо корекції постави в дітей у хронологічній послідовності з метою виявлення внутрішніх та зовнішніх зв'язків, закономірностей та суперечностей;

- використання методу аналізу дозволило виявити особливості порушень постави в дітей із ЗПМР раннього та дошкільного віку;

- метод синтезу дозволив з'єднати окремі ознаки порушень постави в сагітальній площині в дітей;

- за допомогою методу класифікації вдалося створити систему класифікаційних угруповань та виділити зв'язки між ними.

Виклад основного матеріалу. Постава, як частина тіла людини, формується в прямій залежності від певних законів. Так, Л. Бюске вказує на те, що «Людське тіло має складну, але в той самий час таку надійну механіку, яка створена тільки з дуже простих, але хитромудрих механічних принципів ...». Він пропонує до розгляду три закони організації управління тіла: закон рівноваги - фізичне, біологічне (гомеостаз), розумовий; закон економії - має на увазі вітальність (енергетичний капітал), за якої «подих, кровообіг, травлення, статика і локомоторіка повинні споживати малу кількість енергії»; закон комфорту - для комфортабельності життя людина винаходить «компенсуючі схеми, у яких проявляться відносини: «зміст» і «вміст», що існує між фізичною оболонкою (зміст) і вісцеральним наповненням (вміст), між фізичним змістом і психологічним вмістом» (Бюске, 2011, с. 5).

3 іншого боку, «теорія міофасціальних меридіанів являє собою визнання малюнка, властивого скелетно-м'язовій системі як цілому, - лише 
однієї сторони цієї системи в незліченній кількості ритмічних і гармонійних малюнків, які відіграють свою роль у житті нашого тіла. Будучи такою, вона $\epsilon$ лише малою частиною нашого перегляду уявлень про себе не як про «м'які машини» Декарта, але як про інтегровані інформаційні системи - у нелінійній динаміці математики називають такі системи самоорганізуючими, або адаптивними» (Майерс, 2012, с. 2).

Слід зазначити, що м'яз, його фізіологія, не може адаптуватися до статики й обов'язково має ритмічну функцію. При цьому збереження статичного положення тіла знаходиться в прямій залежності від відносин між зміст-вміст і внутрішньої напруги, що вказує на вплив вісцеральної області на вертебральну статику (Бюске, 2011, с. 30-34).

Загальновідомо, що «серед численних фізіологічних функцій організму рухова функція $€$ єдиною, яка забезпечує активний вплив людини на навколишнє середовище, подолання його спротиву, пристосування до умов зовнішнього середовища. Рухи людини підкоряються законам механіки. 3 точки зору механіки, людина являє собою систему рухливо з'єднаних ланок, що володіють певними розмірами, масою, моментами інерції, і забезпечених м'язовими двигунами. Анатомічними структурами, що утворюють ці ланки і з'єднання, є кістки, сухожилля, м'язи і фасції, фіброзні та синовіальні з'єднання кісток, а також внутрішні органи, шкіра тощо» (Дубровский та Федорова, 2003, с. 222).

Крім того, вся м'язова система регулюється певними областями головного мозку і здійснюється за допомогою провідних шляхів. Між висхідними і спадними шляхами сполучення існує певна ієрархія, де ії організація передбачає захист черепа і структур, що знаходяться в них, від паразитуючих периферичних сигналів (Бюске, 2011, с. 35-36).

Рухові ядра стовбура мозку беруть участь у регуляції пози і в підтримці вертикального положення тіла. На цих ядрах перемикаються екстрапірамідні волокна нейронів кори, базальних гангліїв і мозочка. У регуляторній формації і пов'язаних із нею ядрах сигнали, що надходять по цих волокнах від вищих рухових центрів, інтегруються з соматосенсорною інформацією, переданою через спіноталамічні шляхи і з імпульсами від вестибулярної системи. У результаті формуються рухові акти, необхідні для підтримки вертикального положення. Для збереження вертикального положення тіла сила тяжіння повинна протидіяти скороченню розгиначів. Передні дві третини рухових серединних структур стовбура мозку слугують джерелом потужної полегшуючої імпульсації з мотонейронами розгиначів. На цей розгинальний тонус у нормі гальмівний вплив здійснюють сигнали, що йдуть від вищих рухових центрів кори і базальних гангліїв. Функція екстрапірамідної системи бере участь у регуляції пози і здійсненні таких локомоторних актів, як ходьба, поза стоячи, стрибки, біг, плавання тощо (Дубровский та Федорова, 2003, с. 309). 
Особливу роль в утриманні нейтрального положення хребта відіграє м'язовий баланс і симетричність сполучної тканини, що включає:

- рівний рівень сили і гнучкості правої і лівої сторін тіла (двостороння симетрія);

- пропорційне співвідношення сили в протилежних (агоністи/антагоністи) групах м'язів;

- баланс гнучкості, тобто досягнення, але не перевищення нормальних діапазонів руху (Хартер, 2002, с. 50).

3 позицій біомеханіки, вертикальне положення тіла здійснюється за рахунок напруги мускулатури, що бере участь в утриманні тіла і мускулатури, яка не має до даного процесу відношення, що вказує на недостатність диференціювання м'язової системи й відсутність необхідної оптимальної регуляції тонусу м'язів, що є наслідком високого розташування ОЦТ і малої площі опори людини. При цьому постава людини безпосередньо залежить від розподілу геометрії маси тіла, яка $\epsilon$ важливою біологічною характеристикою всього організму (Кашуба, 2003).

Основну роль у формуванні та розвиткові постави відіграє положення хребетного стовпа з його вигинами - лордозу та кіфозу. При цьому вигини варіюються з віком. Так, у новонародженого хребетний стовп прямий і має тільки одну кривизну з опуклістю назад у крижове-куприкової області. Вигини назад (грудний і крижовий) називаються первинними, а вигини вперед (шийний і поперековий) виявляються інверсівними щодо до вихідних заднім опуклостям і являються вторинними. Верхній вторинний вигин формується у плода на сьомому тижні вагітності, а продовжує розвиватися, коли дитина вчиться утримувати голову. Нижній вторинний вигин формується під час освоєння дитиною вертикальних положень (сидячи, стоячи). Формування та розвиток усіх ліній відбувається до припинення росту, тобто до 12-17 років (Нейматов та Сабинин, 2016).

Виходячи з вищесказаного, можна констатувати, що формування та розвиток постави залежать від численних факторів, де базовим є формування кривизн хребта і виробка балансу м'язів, що утримують тіло вертикально.

Ґрунтуючись на загальновідомій класифікації, існуючі порушення постави в сагітальній площині прийнято розділяти на дві категорії: зі збільшенням і зі зменшенням фізіологічних вигинів. До першої категорії належать: сутулість, кругла спина, увігнута спина, кругло-увігнута спина. Другу категорію представляє плоска спина.

Дослідження щодо класифікації порушень постави були розпочаті давно. Так, Stafford (1932) розробив класифікацію, що складається з трьох типів постав:

1) постава з вираженим передне-заднім викривленням хребта (спина кругла; спина плоска; спина вигнута; спина опукло-увігнута); 
2) постава надто напружена;

3) постава з боковим викривленням хребта.

Brown була розроблена гарвардська класифікація постави тіла людини, де представлені 4 типи постав: A - постава досконала; В - постава хороша; 3 постава з незначними порушеннями; D - постава погана (Shell, 1992).

Wolanski (1957) виділяв три типи постави: 1. K - кіфотична постава; 2. Lлордотична постава; 3. R - рівномірна постава (Wolanski, 2012).

Ніколаїв (1954) запропонував класифікацію постави, що складається 3 п'яти типів: нормальна, випрямлена, сутуловата, лордотична, кіфотична (Николаев, 1947).

В. Гамбурцевим було виділено 27 типів постави з урахуванням гоніометричного обстеження хребетного стовпа (Гамбурцев, 1973).

А. Путілова класифікувала поставу за трьома основними групами: 1 зміщення у фронтальній площині; 2 - зміщення в сагітальній площині (зі збільшенням і з сплощенням фізіологічних кривизн); 3 - окомбіновані зміщення (Путилова та Лихварь, 1975).

А. Потапчук і М. Дідур пропонують виділяти поставу, ґрунтуючись на вікових особливостях розвитку: постава дитини дошкільного віку, молодшого шкільного віку, юнаки та дівчата (Потапчук та Дидур, 2001).

В. Кашуба виділяє функціональні й фіксовані порушення постави, які спостерігаються як у сагітальній, так і у фронтальній площинах. У сагітальній площині розрізняють порушення постави зі збільшенням або зменшенням фізіологічних вигинів хребетного стовпа (Кашуба, 2003).

Слід зазначити, що виникнення порушень постави пов'язують із появою деформації в будь-якій частині тіла. При цьому механічна дія на тіло викликає зміни у взаємному розташуванні його частин. Деформація є зміною форм і розмірів тіла, як наслідок змін взаємного розташування точок тіла під впливом зовнішньої або внутрішньої деформуючої сили при механічній напрузі у вигляді розтягування і стиснення. При цьому коливальна система, яка $є$ тілом людини, може бути виведена зі стану рівноваги двома способами: одноразовий зовнішній вплив, який відхиляє одне або декілька тіл системи; одноразовий зовнішній вплив, який повідомляє одному або декільком тілам системи початкові швидкості (Дубровский та Федорова, 2003).

Аналіз спеціальної літератури дозволив виявити основні причини виникнення порушень постави в дітей, які були згруповані нами в декілька блоків:

- біомеханічний (вчення про геометрію мас біоланок тіла людини Кашуби);

- нейрогенно-м'язовий (взаємозв'язок між різними структурами нервової системи, що здійснює регуляцію балансу й тонусу м'язів);

- міофасціальний (вплив збереження певної пози, описаний Майєрсом і більш широко розкритий Васильєвою); 
-психосоматичний (залежність виникнення умов для формування порушень постави в сагітальній площині за Фельденкрайсом);

-компенсаторний (формування первинної і вторинної дуги хребта за Бюском, Нейматовим).

Біомеханічна теорія була описана Кашубою і має на увазі, що «однією 3 причин появи порушень постави $\epsilon$ виникнення надмірно великого перекидаючого моменту щодо однієї або двох площин простору, який займає тіло людини. Це викликає зайву напругу м'язів-розгиначів і деформацію поздовжньої осі хребетного стовпа» (Кашуба, 2003).

Нейроміогенний або нейрогенно-м'язовий блок визначає пряму залежність збереження м'язового тонусу і його балансу під впливом структур нервової системи, що регулює постуральні механізми. Васильєва звертає увагу, що виникнення неврологічної дезорганізації $\epsilon$ наслідком ураження нервової системи на різних рівнях. При цьому вона констатує патобіомеханічні зміни в різних відділах хребта в залежності від зниження тих чи інших рефлексів новонароджених і грудних дітей. Так, дефекти в шийному відділі хребта виражаються в зниженні таких рефлексів: хапального, Робінзона, захисного, долонно-ротового, Моро, шийно-тонічного, розгинання голови в рефлексі Переза, шийного компонента рефлексу Галанта. На тлі цього спостерігається підвищення активності таких рефлексів: крокового, рефлексу повзання, нижнього хапального, рефлексу опори, перехресного рефлексу екстензорів, рефлексу висмикування.

При змінах у грудному відділі хребетного стовпа знижена активність рефлексів: грудного компонента рефлексу Галанта і розгинання грудного відділу хребта в рефлексі Переза.

При патобіомеханічних змінах у поперековому відділі знижена активність рефлексів: крокового, рефлексу повзання, нижнього хапального, рефлексу опори, перехресного рефлексу екстензорів, рефлексу висмикування, зниження поперекового компонента рефлексу Галанта і розгинання поперекового відділу хребта в рефлексі Переза (Васильева, 1999).

Міофасціальний блок причин появи порушень постави вказує на дисбаланс м'язових ланцюгів. Основними міофасціальними лініями, що дозволяють вертікалізувати позу людини, долати падаючий момент тіла вперед i врівноважувати ії за допомогою паритету 3 поверхневою фронтальної лінією (ПФЛ), є поверхнева задня лінія (ПзЛ) та інші розгинальні лінії. При цьому основними анатомічними міофасціальними потягами, що беруть участь в утриманні вертикального положення тіла, $є$ такі:

- поверхнева фронтальна лінія (утримує рівновагу з поверхневою задньою лінією; дає підтримку зверху, підтягуючи й піднімаючи частини скелета, що подовжують лінію гравітації (лобок, грудна клітина, обличчя); підтримує і випрямляє коліна). Вона складається з таких міофасціальних «шляхів» - фасція волосистої частини голови, грудино-ключично- 
соскоподібний м'яз, грудина/грудино-хрящова фасція, прямий м'яз черева, прямий м'яз стегна/квадріцепс, зв'язка надколінка, короткі і довгі розгиначі пальців ноги, передній великогомілковий м'яз, передній відділ гомілки;

-поверхнева задня лінія (бере участь для постави в утриманні тіла у випрямленому положенні і в запобіганні його згортання в позу ембріона). Вона складається 3 таких міофасциальних «шляхів» - надчерепний апоневроз, епікраніальна фасція, крижово-поперекова фасція/м'яз, що випрямляє хребет; крижово-бугорна зв'язка, м'язи задньої поверхні стегна, литковий м'яз/ахіллове сухожилля, підошовна фасція і короткі згиначі пальців ноги (Майерс, 2012).

Слід зазначити, що фасціальна мережа відіграє важливу роль у постуральних механізмах. Вона розглядається як єдине ціле з трьох точок зору:

- фізіологічна - «ціла комунікаційна система»;

- ембріональна - «подвійний мішок»;

- геометрична - «тенсегріті» структура (розгляд скелетноміофасціальної системи в світлі геометрії структур збалансованого стиснення натягу). При цьому фасція є пластичною і, на відміну від м'язу, не прагне повернути свій колишній стан при розтягуванні, а фіксує зміни, будучи деформованою (Майерс, 2012).

Щодо постурального дисбалансу, то можна сказати, що в його формуванні беруть участь кілька м'язів, де укорочені м'язи прагнуть зблизити свої місця прикріплення. «Але та м'язова пара (укорочений м'яз розслаблений м'яз), яка в формуванні постурального дисбалансу $€$ більш біомеханічно значущою, має більший ступінь зміщення своїх місць прикріплення в усіх трьох площинах» (Васильева та Кузнецов, 2011).

Виникнення порушень постави в дітей унаслідок психосоматичних розладів описано Фельденкрайсом, де автор указує, що «будь-які негативні емоції виражаються в вигині». При цьому ознаками психосоматики виступають: захист найуразливіших ділянок тіла (зближення соскоподібного відростка з лобковою кісткою); під час страху - поза ембріона; переляк викликає сверхвипрямлення у верхній частині шиї (Томас Ханн описав це як рефлекс «червоного світла»), а також випрямлення ніг, згинання торса і рук; при депресії сутуляться або задкують; від злості надуваються (Майерс, 2012).

Компенсаторний блок причин появи порушень постави в дітей в сагітальній площині характеризується формуванням та розвитком первинних і вторинних кривизн хребта. При цьому первинні кривизни здійснюють рух уздовж хребта і не беруть до уваги фізіологічні дуги, що існували раніше. Первинний лордоз і первинний кіфоз мають два походження: вертебральний і вісцеральний. Слід зазначити, що вісцеральне походження лордозу пов'язане з перенаповненням, а кіфозу - зі спустошенням, опущенням, спазмом (Бюске, 2011). 
Базуючись на вченні про поділ тіла на функціональні єдності, слід зазначити, що «кожна з них має самостійно вирішувати проблеми, які перед ними поставлені. Якщо цей регіон не може вирішити свої проблеми, сусідні регіони (функціональні єдності) зможуть йому допомогти, перш ніж звернутися, якщо це необхідно до ... глобальної компенсації тіла» (Бюске, 2011, с. 35).

Прийнято виділяти такі функціональні єдності:

- центральна - тулуб;

- периферичні (дві) - таз-нижні кінцівки;

- периферичні (дві) - грудна клітка-верхні кінцівки;

- вища - голова-шия;

- периферична функціональна єдність голови - нижня щелепа.

Вищевказаний розподіл тіла на окремо взяті функціональні єдності може скласти основу класифікації порушень постави у фронтальній (сагітальній) площині в дітей. Орієнтуючись на базовий цефалокаудальний принцип формування скелета дитини, можна було би пропонувати такі підходи до класифікування порушень постави в сагітальній площині:

- вища - надмірна увігнутість або сплощення шийного лордозу;

- периферичні верхні - сутулість або сплощення верхньої частини спини;

- центральні порушення у вигляді круглої спини або сплощення грудного відділу хребта;

- периферичні нижні - увігнута спина або сплощення поперекової частини спини.

Слід зазначити, що найбільш поширеними $€$ комбіновані, змішані варіанти порушень постави, якими є: вище-периферичний верхній; вищецентральний; центрально-периферичний нижній та ін.

Однак, такий поділ порушень постави в сагітальній площині, як система положення скелета (хребта) в просторі на локальні компоненти, з одного боку, значною мірою ускладнює проблему множинністю розглянутих елементів і перевантажує додатковою інформацією, а, з іншого, - віддаляє педагогів від головного в корекційній роботі системного підходу.

При огляді анатомічної будови хребетного стовпа, слід констатувати, що в його різних відділах потрібно розрізняти такі порушення постави:

А) зі збільшенням фізіологічних вигинів:

1 - шийний гіперлордоз;

2 - сутулість;

3 - кругла спина;

4 - увігнута спина;

5 - кругло-увігнута спина;

6 - комбіновані порушення постави.

Б) зі зменшенням фізіологічних вигинів:

1 - шийний гіполордоз; 
2 - сплощення грудного відділу хребта;

3 - поперековий гіполордоз;

4 - плоска спина.

На нашу думку, у попередніх класифікаціях не знаходить відображення таке важливе відхилення в порушеннях постави, як сплощення фізіологічного вигину хребта в тому чи іншому його відділі за винятком плоскої спини, де констатується згладжування грудного й поперекового вигинів через рідкісність зустрічальності в популяції дітей.

Однак, основа класифікації за анатомічною ознакою, де розглядаються в послідовності відділи хребетного стовпа зверху вниз (шийний, грудний, поперековий), не повною мірою відображає численні варіації порушень постави в сагітальній площині в дітей. Тому ми пропонуємо інноваційну класифікацію, засновану на взаємозв'язку між причинами появи патологічних кривизн хребта і адаптовану для фахівців в галузі фізичного виховання дітей, яка відображатиме п'ять етіологічних блоків (табл. 1).

Висновки. Аналіз літературних джерел дозволяє сформулювати такі висновки:

1) проблема порушень постави в дітей раннього та дошкільного віку займає провідні позиції, але при цьому в даної категорії дітей основи етіології $€$ недостатньо висвітленими;

2) основні види порушень постави в дітей представлені таким чином: сутулість, кругла спина, увігнута спина, кругло-увігнута спина, плоска спина;

3) причини появи порушень постави в дітей мають різну природу і залежать від багатьох факторів, які були виділені в декілька блоків: біомеханічний, нейрогенно-м'язовий, міофасціальний, психосоматичний, компенсаторний;

4) основою створення анатомічної класифікації, що враховує зміни кривизни хребта, стало вчення про функціональні єдності Л. Бюска, де знайшли відображення такі порушення постави у фронтальній площині, як: вищі, периферичні верхні, центральні, периферичні нижні;

5) нами була розроблена класифікація, де знайшли відображення п'ять основних етіологічних блоків порушень постави в сагітальній площині в дітей із ЗПМР раннього та дошкільного віку.

Перспективи подальших досліджень можуть полягати в більш докладній деталізації причинно-наслідкових відносин етіології й патогенезу порушень постави в сагітальній площині в даного контингенту дітей. 
Таблиця 1

Класифікація порушень постави в дітей в сагітальній площині

\begin{tabular}{|c|c|c|c|c|c|}
\hline \multirow[b]{2}{*}{$\begin{array}{c}\text { Блоки причин } \\
\text { (етіологія) }\end{array}$} & \multicolumn{5}{|c|}{ Види порушень постави } \\
\hline & $\begin{array}{c}\text { Сутулість із } \\
\text { гіперлордотизацією } \\
\text { шийного відділу }\end{array}$ & $\begin{array}{c}\text { Кругла спина з } \\
\text { гіперкіфотизацією } \\
\text { грудного відділу }\end{array}$ & $\begin{array}{c}\text { Лордотична } \\
\text { постава з } \\
\text { гіперлордозом } \\
\text { поперекового } \\
\text { відділу }\end{array}$ & $\begin{array}{c}\text { Кругло-увігнута спина } \\
\text { з грудним } \\
\text { гіперкіфозом і } \\
\text { поперековим } \\
\text { гіперлордозом }\end{array}$ & $\begin{array}{c}\text { Плоска спина: } \\
\text { шийного, } \\
\text { грудного, } \\
\text { поперекового, } \\
\text { тотального типу }\end{array}$ \\
\hline Біомеханічний & $\begin{array}{lr}\text { Зсув ЦМ } & \text { голови } \\
\text { вперед } & \text { щодо } \\
\text { серединної } & \text { лінії } \\
\text { тіла } & \end{array}$ & $\begin{array}{l}\text { Зсув ЦМ грудної } \\
\text { клітини назад щодо } \\
\text { серединної лінії тіла }\end{array}$ & $\begin{array}{lr}\text { Зсув ЦМ } & \text { живота } \\
\text { (черевної } & \text { області) } \\
\text { вперед } & \text { щодо } \\
\text { серединної } & \text { лінії } \\
\text { тіла } & \end{array}$ & $\begin{array}{l}\text { Зсув ЦМ грудної } \\
\text { клітини назад, а ЦМ } \\
\text { черева - вперед щодо } \\
\text { серединної лінії тіла }\end{array}$ & $\begin{array}{l}\text { Анатомічна } \\
\text { патологія } \\
\text { хребетного } \\
\text { стовпа: } \\
\text { відсутність } \\
\text { фізіологічних } \\
\text { кривизн хребта }\end{array}$ \\
\hline $\begin{array}{l}\text { Нейрогенно- } \\
\text { м'язовий }\end{array}$ & $\begin{array}{l}\text { Наслідки натальної } \\
\text { травми } \\
\text { цервікальної } \\
\text { локалізації }\end{array}$ & $\begin{array}{l}\text { Наслідки натальної } \\
\text { травми шийно- } \\
\text { верхньогрудного } \\
\text { відділу хребта }\end{array}$ & $\begin{array}{l}\text { Наслідки натальної } \\
\text { травми грудо- } \\
\text { поперекового } \\
\text { відділу хребта }\end{array}$ & $\begin{array}{lr}\text { Наслідки } & \text { поєднаної } \\
\text { натальної } & \text { травми } \\
\text { шийного } & \text { і } \\
\text { поперекового } & \text { відділів } \\
\text { хребта } & \\
\end{array}$ & $\begin{array}{l}\text { Наслідки } \\
\text { черепно- } \\
\text { мозкової } \\
\text { травматизації } \\
\text { при пологах }\end{array}$ \\
\hline $\begin{array}{l}\text { Міофасціаль- } \\
\text { ний }\end{array}$ & $\begin{array}{l}\text { Переважання на- } \\
\text { пруги в поверх- } \\
\text { невій фронтальній } \\
\text { лінії (ПФл): } \\
\text { грудино-ключично- } \\
\text { соскоподібного } \\
\text { м'яза, } \\
\text { грудино/грудино- } \\
\text { хрящова фасція }\end{array}$ & $\begin{array}{l}\text { Слабкість } \\
\text { поверхневої задньої } \\
\text { лінії (ПзЛ): } \\
\text { епікраніальна } \\
\text { фасція, крижово- } \\
\text { поперекова фасція / } \\
\text { м'яз, що випрямляє } \\
\text { хребет }\end{array}$ & $\begin{array}{l}\text { Переважання } \\
\text { напруги в поверх- } \\
\text { невій задній лінії } \\
\text { (Пзл): крижово- } \\
\text { поперекова фасція } \\
\text { / м'яз, що } \\
\text { випрямляє хребет, } \\
\text { крижово-бугорна } \\
\text { зв'язка }\end{array}$ & $\begin{array}{l}\text { Дисбаланс в напрузі } \\
\text { поверхневих } \\
\text { передньої і задньої } \\
\text { ліній }\end{array}$ & $\begin{array}{l}\text { Надмірне } \\
\text { напруження в } \\
\text { обох } \\
\text { міофасциальних } \\
\text { лініях: ПФЛ і } \\
\text { ПзЛ }\end{array}$ \\
\hline
\end{tabular}




\begin{tabular}{|c|c|c|c|c|c|}
\hline $\begin{array}{l}\text { Психосоматич- } \\
\text { ний }\end{array}$ & $\begin{array}{l}\text { Страхи (фобії), } \\
\text { депресія, } \\
\text { невпевненість у } \\
\text { собі, боязкість, } \\
\text { проблеми в родині }\end{array}$ & $\begin{array}{lr}\text { Страх, } & \text { депресія, } \\
\text { відчай, } & \text { безвихідь, } \\
\text { туга, } & \text { самотність, } \\
\text { проблеми в родині }\end{array}$ & $\begin{array}{l}\text { Невпевненість у } \\
\text { собі, тривожність, } \\
\text { сумніви }\end{array}$ & $\begin{array}{l}\text { Боязнь, страх, } \\
\text { невпевненість у собі, } \\
\text { боязкість, сумніви }\end{array}$ & $\begin{array}{l}\text { Захисне } \\
\text { напруження } \\
\text { м'язів } \\
\text { хребетного } \\
\text { стовпа } \\
\end{array}$ \\
\hline $\begin{array}{l}\text { Компенсатор- } \\
\text { ний }\end{array}$ & $\begin{array}{l}\text { Зсув } \\
\text { (зісковзування) } \\
\text { вперед шийних } \\
\text { хребців }\end{array}$ & $\begin{array}{lr}\text { Зсув } & \text { (зісковзування) } \\
\text { назад } & \text { грудних } \\
\text { хребців }\end{array}$ & $\begin{array}{l}\text { Зсув } \\
\text { (зісковзування) } \\
\text { вперед } \\
\text { попереково- } \\
\text { крижових хребців }\end{array}$ & $\begin{array}{l}\text { Травматична } \\
\text { дислокація хребців у } \\
\text { шийно- } \\
\text { верхньогрудному і } \\
\text { грудо-поперековому } \\
\text { відділах хребта }\end{array}$ & $\begin{array}{l}\text { Наслідок } \\
\text { аномалій } \\
\text { розвитку } \\
\text { хребетних } \\
\text { анатомічних } \\
\text { структур }\end{array}$ \\
\hline
\end{tabular}




\section{ЛITEPATУРА}

Бюске, Л. (2011). Мышечные цепи. Том 2. Лордозы-кифозы-сколиозы и дерормации грудной клетки. Санкт-Петербург: Меридиан-C (Biuske, L. (2011). Muscle chains. Volume 2. Lordosis-kyphosis-scoliosis and chest deformity. St. Petersburg: Meridian-S).

Валецька, Р. О. (2007). Педіатрія: підручник. Луцьк: Волинь. кн. (Valetska, R. O. (2007). Pediatrics: textbook. Lutsk: Volyn).

Васильева, Л. Ф. (1999). Алгоритмы мануальной диагностики и терапии патобиомеханических изменений мышечно-скелетной системы. Новокузнецк (Vasilieva, L. F. (1999). Manual diagnosis and therapy algorithms of pathobiomechanical changes in the musculoskeletal system. Novokuznetsk).

Васильева, Л. Ф., Кузнецов, О. В. (2011). Мышечно-фасциальные цепи туловища и нижних конечностей (клиника, диагностика, лечение). Часть 1. Москва (Vasilieva, L. F. \& Kuznetsov, O. V. (2011). Muscle-fascial chains of the trunk and lower extremities (clinic, diagnosis, treatment). Part 1. M oscow).

Гамбурцев, В. А. (1973) Гониометрия человеческого тела. М.: Медицина (Hamburtsev, V. A. (1973). Goniometry of the human body. M.: M edicine).

Глоба, О. П. (2011). Регіональне реабілітаційне середовище як фрактор соціалізації дітей і молоді з обмеженими психофрізичними можливостями. Краматорськ: ДДМА (Globa, О. Р. (2011). Regional rehabilitation environment as a factor of socialization of children and young people with disabilities. Kramatorsk: DDM A).

Дубровский, В. И., Федорова, В. Н. (2003). Биомеханика: учеб. для сред. и высш. учеб. заведений. М.: Изд-во ВЛАДОС-ПРЕСС (Dubrovskyi, V. I. \& Fedorova, V. N. (2003). Biomechanics: Textbook for secondary and higher education institutions. $M$.: Publishing house VLADOS-PRESS).

Кашуба, В. А. (2003). Биомеханика осанки. Киев: Олимпийская литература (Kashuba, V. A. (2003). Biomechanics of posture. Kyiv: Olympic literature).

Майерс, Т. В. (2012). Анатомические поезда. Миофасциальные меридианы для мануальной и спортивной медицины. Перевод с англ. Ю. С. Воробьёвой. СанктПетербург (M yers, T. V. (2012). Anatomical trains. M yofascial meridians for manual and sports medicine. St. Petersburg).

Нейматов, Э. М., Сабинин, С. Л. (2016). Прикладная биомеханика в спортивной медицине и остеопатии. Москва: ООО «Издательство «Медицинское информационное агентство» (Neymatov, E. M., Sabinin, S. L. (2016). Applied biomechanics in sports medicine and osteopathy. Moscow: LLC "Publishing House" Medical Information Agency").

Николаев, Л. П. (1947). Руководство по биомеханике в применении к ортопедии, травматологии и протезированию. К.: Медицина (Nikolaiev, L. P. (1947). Guide to biomechanics as applied to orthopedics, traumatology and prosthetics. K.: M edicine).

Потапчук, А. А., Дидур, М. Д. (2001). Осанка и физическое развитие детей: программы диагностики и коррекции нарушений. СПб.: Питер (Potapchuk, A. A., Didur, M. D. (2001). Posture and physical development of children: programs for the diagnosis and correction of disorders. St. Petersburg: Piter).

Путилова, А. А., Лихварь, А. Т. (1975). Сколиозная болезнь. К.: Здоров'я (Putilova, А. А. \& Likhvar, A.T. (1975). Scoliosis disease. K.: Zdorovie).

Хартер, Р. А. (2002). Основы анатомии и прикладной кинезиологии (лП) (Harter, R. А. (2002). Fundamentals of anatomy and applied kinesiology (LP)).

Snell, R. S. (1992). Clinical Anatomy for Medical Stunts, 4th. ed. Boston: Little, Brown and Company.

Wolanski, N. (2012). Rozw oj biologiczny czlowieka. Warszawa: PWN Scientific Publisher. 


\section{PEЗЮME}

Беседа Владимир. Виды и причины нарушений осанки в сагиттальной плоскости у детей раннего и дошкольного возраста с задержкой психомоторного развития.

Целью данной статьи является создание классификации нарушений осанки в сагиттальной плоскости детей раннего и дошкольного возраста с задержкой психомоторного развития. Анализ литературных источников позволил выделить основные этиологические признаки нарушений осанки у данной категории детей, что позволило определить их в блоки и сформировать классификацию нарушений осанки, которая облегчает педагогам ориентиры в отклонениях осанки у детей.

Перспективы дальнейших исследований могут лежать в русле более подробной детализации причинно-следственных отношений этиологии и патогенеза нарушений осанки в сагиттальной плоскости.

Ключевые слова: дети, осанка, нарушения осанки, позвоночник, кифоз, лордоз, диагностика.

\section{SUM MARY}

Biesieda Volodymyr. Types and causes of position disorders in the sagittal plane in children with psychomotor retardation of early and preschool age.

Now, disorders of posture in the sagittal plane in children occupy one of the leading places in the pathology of the musculoskeletal system and make up 70-80 \% in preschool children.

This indicates the relevance of finding a solution to the problem of prevention and posture correction, which has a direct impact not only on the development of the child, but also on the body as a whole.

The results of numerous studies indicate that pathological posture affects occurrence of the following negative factors: development of a stable pain syndrome; formation of a pathological motor stereotype; development of functional articular blockade; occurrence of myofascial pain syndrome; change in the biomechanics of the spine and body in general; development of degenerative changes in the intervertebral disks and ligament-joint apparatus; development of osteochondrosis; development of herniated intervertebral discs; changes in the topography of the chest; deterioration of the abdominal organs; insufficient diaphragm mobility and reduced fluctuations in the intrathoracic and intra-abdominal pressure; negative effect on the cardiovascular system; digestive dysfunction; deterioration of the central nervous system, etc.

Moreover, the main types of posture disorders in children are presented as follows: stoop, round back, concave back, round-concave back, flat back.

We considered the main reasons for the occurrence of posture disorders in children, which have a different nature and were distinguished in several blocks: biomechanical, neurogenic-muscular, myofascial, psychosomatic, compensatory.

On the basis of these etiological, that is, primary causes, a classification was formed that facilitates teachers' guidance in deviations in posture in children.

Prospects for further research may lie in a more detailed explanation of the causal relationship of the etiology and pathogenesis of postural disorders in the sagittal plane.

Key words: children, posture, disorders of posture, spine, kyphosis, lordosis, diagnosis. 